\title{
超高純度金属材料
}

新藤裕一朗 $*$

\section{Ultra High Purity Materials}

\section{Yuichiro Shindo}

\section{Synopsis}

Ultra high purity materials have developed with the semiconductor material. Furthermore, these materials have attractive characteristics to conventional materials. Ultra high purity materials have been obtained high electrical and thermal conductivity at low temperature, lower hardness, lower softening temperature, lower deformation resistance (high workability), higher Residual Resistivity Ratios (RRR) due to less non-metallic inclusion and voids. These properties have not been recognized in the conventional materials. Ultra high purity materials have been expected to be useful for semiconductor application, $\mathrm{MoSi}_{2}$ heater, freezing point measurement, analysis standard sample, high temperature application, bonding wire and so on.

\section{1. 緒言}

産業の米といわれている半導体が, 重厚長大を代表す る材料 $\mathrm{Fe}$ から主役の座を奪って久しい. その半導体も高 集積化が進むにつれてプロセスの微細化が進み, ナノレ ベルの世界へ突入しょうとしている. また，そこに使用さ れる半導体材料も, Table 1 に示すように変遷してきてい る. $\mathrm{Al}$ から出発し, W, Mo, Ti さらには $\mathrm{Co}, \mathrm{Cu}, \mathrm{Ta}$ など種々 の高純度金属材料が使用され，要求されてきた。この高純 度金属は,さらにナノテクノロジーという大きな新分野 に使用されつつある.ナノレベルの世界では, 当然のこと ながら微量の不純物が悪影響を及ぼすからである。ナノ メタラジーは, 金属材料の組成, 組織, 構造などをナノレ ベルで制御し，新たなナノメタルを創出するようになる。
現在工業的に使用されている金属の性質は, 純度 $2 \mathrm{~N}$ (99\%) から $3 \mathrm{~N}(99.9 \%)$ の金属材料の特性であり, その特 性は不純物により変化した結果であり,その金属そのも のの特性を十分に反映しているとはいえない.たとえば, Fe は一般に錆びやすく低温で脆い性質を有すると教えら れてきたが, 高純度化したFeは錆びにくく, その耐食性は 環境によっては金に匹敵することや, 低温 $($ こ $200 \mathrm{~K})$ は もちろんのこと, 極低温（～20 K ）でも可塑性を有するこ となど,これまでの常識から理解できない現象がつぎつ ぎと見出されてきている ${ }^{1)}$.このように超高純度金属材料 は, 材料の基本である熱力学, 物理化学的性質, 力学特性 などのこれまでの知識を根本的に変える可能性を有して いる.このことから, 各種金属も超高純度化すれば, 新た に新世界が開けてくる。

Table 1. Roadmap of semiconductor materials.

\begin{tabular}{|c|c|c|c|c|c|c|c|c|c|c|c|}
\hline Year of production & 1970 & 1976 & 1982 & 1985 & 1988 & 1922 & 1995 & 1998 & 2000 & 2002 & 2005 \\
\hline DRAM & $1 \mathrm{~K}$ & $16 \mathrm{~K}$ & $256 \mathrm{~K}$ & $1 \mathrm{M}$ & $4 \mathrm{M}$ & $16 \mathrm{M}$ & $64 \mathrm{M}$ & $256 \mathrm{M}$ & $1 \mathrm{G}$ & $4 G$ & $16 \mathrm{G}$ \\
\hline Gate materials & $\mathrm{Al}$ & Poli-Si & $\mathrm{MoSi}_{2}$ & \multicolumn{2}{|c|}{$\mathrm{WSi}_{2}$} & \multicolumn{3}{|c|}{$\mathrm{TiSi}_{2}$} & \multicolumn{2}{|c|}{$\mathrm{CoSi}_{2}$} & $\mathrm{NiSi}$ \\
\hline Gate insulator & \multicolumn{8}{|c|}{$\mathrm{SiO}_{2}$} & \multicolumn{2}{|c|}{ SiON } & HfSiON \\
\hline Interconnect & \multicolumn{2}{|c|}{$\mathrm{Al}$} & \multicolumn{4}{|c|}{ Al-Si/TiN } & \multicolumn{2}{|c|}{$\mathrm{Al}-\mathrm{Cu} / \mathrm{TiN}$} & & $\mathrm{Cu} / \mathrm{TaN}$ & \\
\hline
\end{tabular}


本論文では, 金属の高純度化方法について簡単に述べ, その金属の特性の一部を超高純度 $\mathrm{Cu}$ を中心に報告し, 最 後に将来の展望について述べる.

\section{2. 高純度金属の製造方法}

市販されている金属の純度は, 通常 $2 \mathrm{~N}(99 \%) \sim 4 \mathrm{~N}$ (99.99％)である。これらの金属を高純度化する場合, 大 きく分けて湿式精製法と乾式精製法がある。湿式精製法 では電解, 再結晶, イオン交換, 溶媒抽出法などがあり, 乾式精製法では蒸留, 帯溶融精製, 固相電解, 真空溶解な どがある。必要に応じて,これらの精製法を組み合せて実 施する。主な精製法について Table 2 に簡単にまとめた が,この表で示したものは, ほんの一例に過ぎない，

$\mathrm{Cu}$ を例にとって述べると, 一般的な高純度化方法は Table 32 2) のようになる. 電解法の繰返し以外に帯溶融精 製を何度も繰返して高純度化する, その中で, 最高純度を 出しているのが, 带溶融精製の中でも浮遊带溶融精製法
である. 出発原料は, 硝酸浴電解精製したRRR=10000の高 純度銅から作製したロッドであり これを浮遊帯溶融精 製法で 9 回精製後真空焼きなましを行っている.この結 果, 帯溶融のスタート側でRRR=22000の值を得ており, 極 めて高純度化されたことが確認できる。帯溶融精製法で は, 素材の表面清浄, 脱ガス, 容器材質, 䨌囲気などが重 要となる.ここで, RRR とは残留抵抗比 (Residual Resistivity Ratios : RRR) の略で, 温度 $293 \mathrm{~K}$ と $4.2 \mathrm{~K}$ との比抵抗の比 であり, 純度評価の判定の一つに用いられる. しかし, 含 有される不純物の種類によって值がある程度左右される という久点を有するが, 総合的な純度を評価するのに最 適であり，RRRが高いほど純度が良いことを表している。 ここで，日鉱金属(株）(以下，当社という）で製造している 高純度 $\mathrm{Cu}$ の不純物分析と RRR 值の一例を Table 4 に示 す. 不純物分析結果と RRR を示している. 不純物分析測 定方法は, Glow Discharge Mass Spectrometry（グロー放電 質量分析法：GD-MS）を採用している. GD-MS は, 試料

Table 2. Purification process of metal.

\begin{tabular}{c|c|l}
\hline & Purification method & \multicolumn{1}{|c}{ Property utilized } \\
\hline \multirow{4}{*}{$\begin{array}{c}\text { Hydro- } \\
\text { metallurgical } \\
\text { purification }\end{array}$} & Selective precipitation & Solubility \\
\cline { 2 - 3 } & Cementation & Electrode potential \\
\cline { 2 - 3 } & $\begin{array}{c}\text { Electro winning } \\
\text { Electro refining }\end{array}$ & Electrode potential \\
\cline { 2 - 3 } & Ion exchange & Distribution of dissolved ions between phases \\
\hline \multirow{4}{*}{$\begin{array}{c}\text { Pyro- } \\
\text { metallurgical } \\
\text { purification }\end{array}$} & Solvent extraction & Distribution of dissolved ions between phases \\
\cline { 2 - 3 } & $\begin{array}{c}\text { Distillation } \\
\text { Sublimation }\end{array}$ & Vapor pressure \\
\cline { 2 - 3 } & $\begin{array}{c}\text { Zone melting } \\
\text { Fractional crystallization }\end{array}$ & Distribution of atoms between solid and liquid phases \\
\cline { 2 - 3 } & Electro transport & Ion mobility \\
\hline
\end{tabular}

Table 3. Refining process of $\mathrm{Cu}$.

\begin{tabular}{|c|c|c|}
\hline & Purification process & Purity \\
\hline 1 & $\begin{array}{c}\text { Re-electro refining (sulphate) } \rightarrow \text { Oxidation melting } \rightarrow \\
\left.3^{\text {rd }} \text {-electrorefing(nitrate: }\right) \rightarrow \text { Atmosphere melting Continuous casting }\end{array}$ & $5 \mathrm{~N}$ \\
\hline 2 & $\begin{array}{c}\text { Re-electro refining( sulphate: several pass) } \rightarrow \text { Zone refining(several pass) } \\
\text { Re-electro refining( sulphate : several pass) } \rightarrow \text { Vacuum melting } \rightarrow \\
\text { Zone refining(several pass) }\end{array}$ & $\begin{array}{c}>5 \mathrm{~N} \\
\mathrm{RRR}=3000 \sim 6000\end{array}$ \\
\hline 3 & Re-electro refining(2 pass) $\rightarrow$ De-sulphurization-zone refining (3 pass) & $\begin{array}{c}6 \mathrm{~N} \\
\mathrm{RRR}=900 \sim 1160\end{array}$ \\
\hline 4 & $\begin{array}{c}\text { Refining } \rightarrow \text { Melting } \rightarrow \text { Casting } \\
\text { Use of pure water and clean room, clean of circumstance }\end{array}$ & $\begin{array}{c}6 \mathrm{~N} \\
\mathrm{RRR}=4000\end{array}$ \\
\hline 5 & $\begin{array}{c}\text { Re-electro refining(sulphate) } \rightarrow \text { Vacuum casting } \\
\text { Re-electro refining (sulphate) } \rightarrow \text { Zone refining(several pass) }\end{array}$ & $\begin{array}{l}5 \mathrm{~N} \text { RRR }=824 \\
7 \mathrm{~N} \mathrm{RRR}=5450\end{array}$ \\
\hline 6 & $\begin{array}{l}\text { Re-electro refining (sulphate) +Electro refining(nitrate:3 pass) } \\
\rightarrow \text { Vacuum melting Continuous casting }\end{array}$ & $7 \mathrm{~N}$ \\
\hline 7 & Electrolysis $\rightarrow$ Zone refining(repeat) & $8 \mathrm{~N}$ \\
\hline 8 & $\begin{array}{c}\text { Re-electro refining(several pass) } \rightarrow \text { Crucible melting } \rightarrow \\
\text { Floating-zone melting }(9 \text { pass })\end{array}$ & $R R R=22000$ \\
\hline
\end{tabular}


Table 4. Typical analysis of several coppers.

\begin{tabular}{c|c|c|c|c}
\hline Element & $\begin{array}{c}\text { Commercial } \\
(\text { OFC:4 N) }\end{array}$ & $\begin{array}{c}\text { High purity } \\
\mathrm{Cu}(6 \mathrm{~N})\end{array}$ & $\begin{array}{c}\text { Ultra high } \\
\text { purity Cu (9 N) }\end{array}$ & Unit \\
\hline $\mathrm{Na}$ & 0.01 & $<0.01$ & $<0.005$ & $\mathrm{ppm}$ \\
\hline $\mathrm{K}$ & 0.2 & $<0.01$ & $<0.01$ & $\mathrm{ppm}$ \\
\hline $\mathrm{U}$ & $<0.1$ & $<0.1$ & $<0.1$ & $\mathrm{ppb}$ \\
\hline $\mathrm{Th}$ & $<0.1$ & $<0.1$ & $<0.1$ & $\mathrm{ppb}$ \\
\hline $\mathrm{Fe}$ & 0.15 & 0.02 & $<0.001$ & $\mathrm{ppm}$ \\
\hline $\mathrm{Ni}$ & 0.02 & $<0.005$ & $<0.001$ & $\mathrm{ppm}$ \\
\hline $\mathrm{Ag}$ & 8 & 0.2 & $<0.005$ & $\mathrm{ppm}$ \\
\hline $\mathrm{Cr}$ & $<0.01$ & 0.02 & $<0.005$ & $\mathrm{ppm}$ \\
\hline $\mathrm{S}$ & 10 & $<0.005$ & $<0.005$ & $\mathrm{ppm}$ \\
\hline $\mathrm{As}$ & 0.1 & $<0.005$ & $<0.005$ & $\mathrm{ppm}$ \\
\hline $\mathrm{Sb}$ & 0.03 & $<0.005$ & $<0.005$ & $\mathrm{ppm}$ \\
\hline $\mathrm{Bi}$ & 0.02 & $<0.001$ & $<0.001$ & $\mathrm{ppm}$ \\
\hline $\mathrm{Al}$ & 1.5 & 0.05 & $<0.001$ & $\mathrm{ppm}$ \\
\hline $\mathrm{C}$ & $<10$ & $<1$ & $<1$ & $\mathrm{ppm}$ \\
\hline $\mathrm{O}$ & 75 & $<1$ & $<1$ & $\mathrm{ppm}$ \\
\hline $\mathrm{N}$ & $<10$ & $<1$ & $<1$ & $\mathrm{ppm}$ \\
\hline $\mathrm{RRR}$ & 100 & 18000 & 45000 & \\
\hline & & & &
\end{tabular}

Table 5. RRR value of various coppers.

\begin{tabular}{c|c|c}
\hline Purity & Reference & NMM \\
\hline $4 \mathrm{~N}$ & $100 \sim 550$ & - \\
\hline $6 \mathrm{~N}$ & $900 \sim 7500$ & 18000 \\
\hline $7 \mathrm{~N}$ & 9500 & - \\
\hline $9 \mathrm{~N}$ & - & $38000 \sim 45000$ \\
\hline Highest value (past) & 36000 & - \\
\hline
\end{tabular}

をグロー放電により原子化およびイオン化し，イオン化し た目的元素を質量分析により定量する方法で, 固体のまま 直接定量でき, 高感度にほぼ全元素を迅速に測定できる. 純度が $9 \mathrm{~N}$ になると, 全ての不純物元素が分析下限值以下 となり, RRR も 45000 と非常に高い值を示している. 各種 純度によるRRRの結果を, Table 52)〜5)に示す. 市販され ている純度 $4 \mathrm{~N}$ レベルの $\mathrm{Cu}$ は文献によると約 $100 \sim 550$ と非常に低く, 純度 $6 \mathrm{~N}$ レベルでは約 $900 ７ 500$ の值を 示す. 過去において, 文献で報告されている值の最高值 ${ }^{3)}$ は 36000 である。一方, 当社 $\mathrm{Cu}$ の RRR は $6 \mathrm{~N}$ で 18000 で あり, $9 \mathrm{~N}$ で $38000 〜 45000$ と非常に高い值となっている.

\section{3．超高純度金属材料の性質および用途}

ここでは，主に $\mathrm{Cu}, \mathrm{Ti}$ ，合金を例にとって報告する。

\section{1 超高純度 $\mathrm{Cu}$}

IT 技術の進展に伴い, 近年, 銅に対する要求がより高純 度，高強度にと極限化してきている．純銅の中には，比較 的高純度品といわれている $4 \mathrm{~N} \sim 5 \mathrm{~N}$ レベルの無酸素銅 (Oxygen Free Copper : OFC) や（超）高純度銅と呼ばれて
いる $6 \mathrm{~N} \sim 9 \mathrm{~N}$ レベルの銅がある.ここでは, 半導体ス パッタリング用 $\mathrm{Cu}$ ターゲットを例に用いて, 純度 $6 \mathrm{~N}$ の 高純度銅の特性について説明する。

現在, LSI 配線には $\mathrm{Al}$ あるいは $\mathrm{Al}$ 合金 $(\mathrm{Al}-\mathrm{Cu}-\mathrm{Si})$ が 使用されているが, LSI 設計寸法の微細化に伴い $\mathrm{Al}$ よりも 比抵抗の小さな金属が求められている. Table 6 は, 配線 材料の物性を比較したものである。この表で明らかなよ うに $\mathrm{Cu}$ は $\mathrm{Al}$ よりも比抵抗が小さくかつ融点が高いため, エレクトロマイグレーションにも強いという特性を有し ている。このような優位性から近年, $\mathrm{Cu}$ 配線が盛んに使 用されている. $\mathrm{Cu}$ 配線の簡単な模式図を, Fig.1 に示す. バリア層 (TaN), $\mathrm{Cu}$ シード層, $\mathrm{Cu}$ 配線の 3 層構造で形成 されており,バリア層および $\mathrm{Cu}$ シード層は一般にスパッ タリング法によって形成される。Cu シード層に要求され る特性として, a) 比抵抗が小さいこと b) 膜に欠陥（パー ティクル）がないことなどが挙げられる.

非磁性体である純 $\mathrm{Cu}$ の電気抵抗 $\rho$ は, Matthiessen の 法則から式 (1)で表されることが知られている.

$\rho=\rho_{0}+\rho_{\mathrm{t}}$ 
Table 6. Physical properties comparison of interconnect metal.

\begin{tabular}{c|c|c|c|c|c|c}
\hline Metal & $\begin{array}{c}\text { Melting point } \\
\left({ }^{\circ} \mathrm{C}\right)\end{array}$ & $\begin{array}{c}\text { Resistance } \\
(\mathrm{m} \Omega \mathrm{cm})\end{array}$ & $\begin{array}{c}\text { Oxidation } \\
\text { resistance }\end{array}$ & $\begin{array}{c}\text { Heat rate of } \\
\text { expansion } \\
(\mathrm{ppm} / \mathrm{k})\end{array}$ & $\begin{array}{c}\text { Self diffusion } \\
\mathrm{D}_{0}\left(\mathrm{~cm}^{2} / \mathrm{s}\right)\end{array}$ & $\begin{array}{c}\text { Self diffusion } \mathrm{E}_{\mathrm{a}} \\
(\mathrm{eV})\end{array}$ \\
\hline $\mathrm{Al}$ & 660 & $2.6 \sim 3$ & Good & 29 & 1.7 & 1.5 \\
\hline $\mathrm{Cu}$ & 1083 & 1.68 & Bad & 17 & 0.35 & 2.1 \\
\hline $\mathrm{Ag}$ & 961 & 1.62 & Fair & 19 & 0.24 & 1.9 \\
\hline $\mathrm{Au}$ & 1063 & 2.38 & Good & 14 & 0.091 & 1.8 \\
\hline $\mathrm{W}$ & 3410 & 5.52 & Fair & 4.6 & - & $>3$ \\
\hline
\end{tabular}

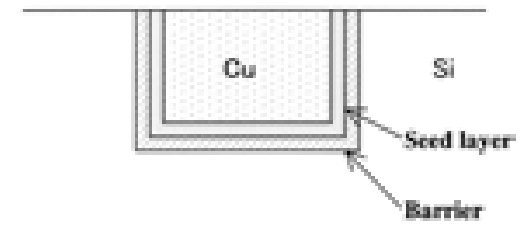

Fig.1. Diagram of $\mathrm{Cu}$ conductor interconnect.

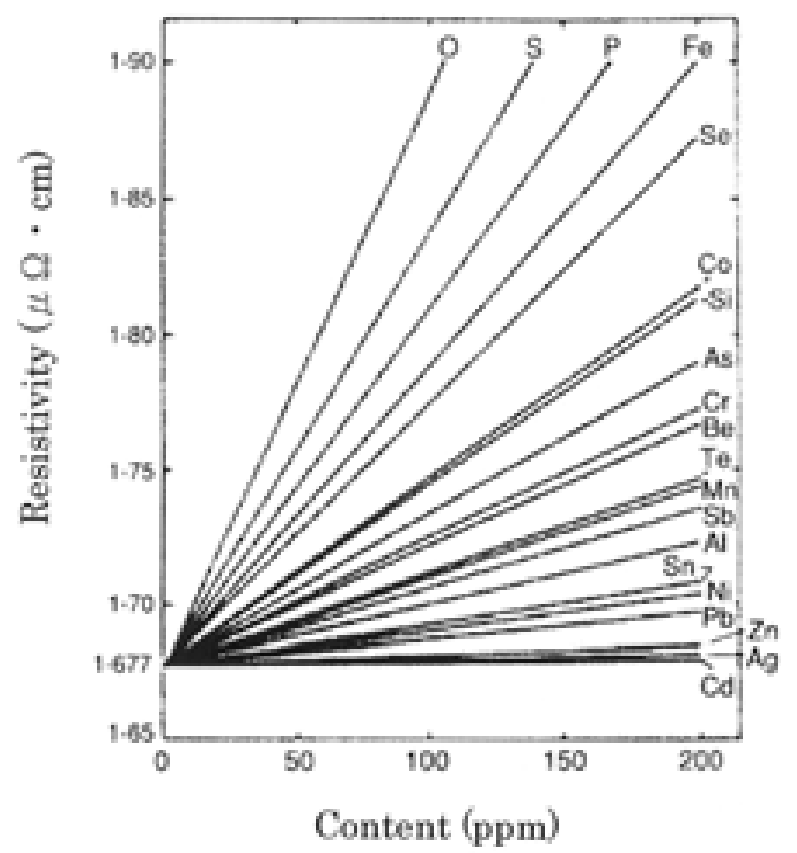

Fig.2. Relationship between electrical resistively and additional elements ${ }^{3)}$.

ここで, $\rho_{0}$ : 残留抵抗, $\rho_{\mathrm{t}}$ : 格子振動に起因する抵抗を 表す， $\rho_{\mathrm{t}}$ は温度に依存する項で物質固有の值を示す。一 方, $\rho_{0}$ は原子空孔, 転位, 不純物などに大きく依存する. Fig.2 に純 $\mathrm{Cu}$ の電気抵抗に及ぼす微量不純物の影響を示 す6).この図より $\mathrm{Cu}$ の電気抵抗上昇に $\mathrm{O}, \mathrm{S}, \mathrm{P}, \mathrm{Fe}$ など の不純物が大きく寄与することがわかる.したがって，

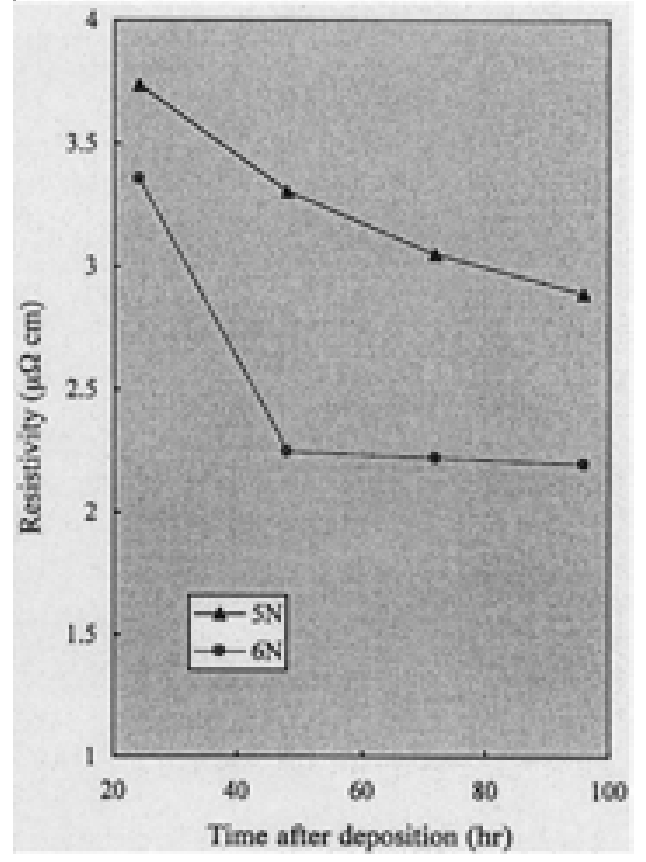

Fig.3. Resistivity after sputtering ${ }^{7}$.

$\mathrm{Cu}$ シード層をスパッタリング法で成膜する際, 使用する $\mathrm{Cu}$ ターゲットには, 上記不純物元素が極力低減されたも のが要求される.当社で高純度化した超高純度 $\mathrm{Cu}$ 夕ー ゲット $(6 \mathrm{~N})$ と市販されている純度 $5 \mathrm{~N}$ レベルの無酸素銅 ターゲットを用いて, 成膜した $\mathrm{Cu}$ 薄膜のシート抵抗を比 較した結果を, Fig.3 に示す。なお，用いた OFC ターゲッ トと高純度 $\mathrm{Cu}$ ターゲットの純度は, Table 4 に示している 值とほぼ同様である。 $\mathrm{O}, \mathrm{S}, \mathrm{Fe}$ 含有量の高い $\mathrm{OFC}$ ター ゲットを用いて成膜した $\mathrm{Cu}$ 薄膜のシート抵抗は $250 \mathrm{~m} \Omega$ 前後であるのに対し, 高純度 $\mathrm{Cu}$ ターゲットを用いたもの は約 $235 \mathrm{~m} \Omega$ となり, OFC に比較し約 $5 \sim 6 \%$ 抵抗值が減 少している. 高純度 $\mathrm{Cu}$ は, 不純物元素含有量が少なく,さ らに不純物元素による粒界のピンニング効果が少ないた め, 室温でも粒成長が起きてシート抵抗が低下したと考 
えられる. また, 低温でも容易に結晶粒径の粗大化が起こ るため, エレクロマイグレーション特性, メッキ下地など に有利に働くという利点もある.

スパッタリングした場合，スパッタリングによる薄膜 形成時にパーティクルと呼ばれる欠陥が生じ，この欠陥 は半導体の製造歩留りを低下させることがある.Fig.4は， $\mathrm{Cu}$ 薄膜上に存在するパーティクル数を, OFC ターゲット

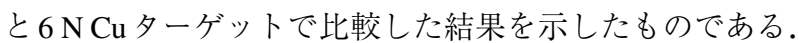
純度 $5 \mathrm{~N}$ の OFC ターゲットを用いた場合のパーティクル 数は約 40 個であるのに対し, 純度 $6 \mathrm{~N}$ の高純度 $\mathrm{Cu}$ ター ゲットでは 10 個以下となり, 著しくパーティクル数が減 少する ${ }^{7)}$. OFC ターゲットのパーティクルが多い理由は, 不純物である $\mathrm{O}, \mathrm{S}$ の $\mathrm{Cu}$ 中への室温における固溶限が数 ppm以下と非常に小さいため, 結晶粒界上に偏析した酸化 物あるいは硫化物が介在物となって，スパッタリング中 に成膜面上に飛来するためであると推察される。

$\mathrm{Cu}$ 配線は, $\mathrm{Cu}$ シード層をスパッタで成膜した後に電気 メッキにより形成される。電気メッキする際，用いられる アノードの純度や液の純度に配線の膜は影響される。例 えば, 液組成を同一とし，アノードに純度の異なる $\mathrm{Cu}$ を 用いて室温で電気メッキし，その膜を熱処理した場合の 結果をFig.5, Fig.6 に示す.カソードに電着した $\mathrm{Cu}$ 中の 膜の硬度は，メッキ直後は純度によらずほとんど差は見 られない。しかし，時間が経過するにつれて，用いたア ノードの純度がよいほど硬さは低くなり，9N Cuをアノー ドに用いた場合が一番低い硬さになっている．また，膜中 の不純物を分析した結果，やはり高純度のものを用いた ほうが不純物量は低いことも判明している. Fig.6から, 膜 の硬さは, 膜中の不純物含有量の合計量に大きく依存す ることがわかる。

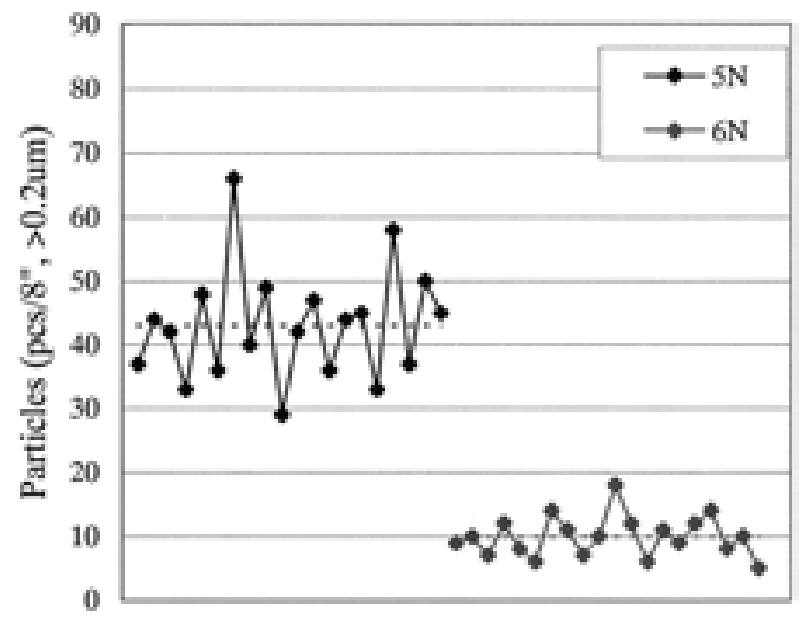

Fig.4. Comparison of particle number between $5 \mathrm{~N} \mathrm{Cu}$ and $6 \mathrm{~N} \mathrm{Cu}$.

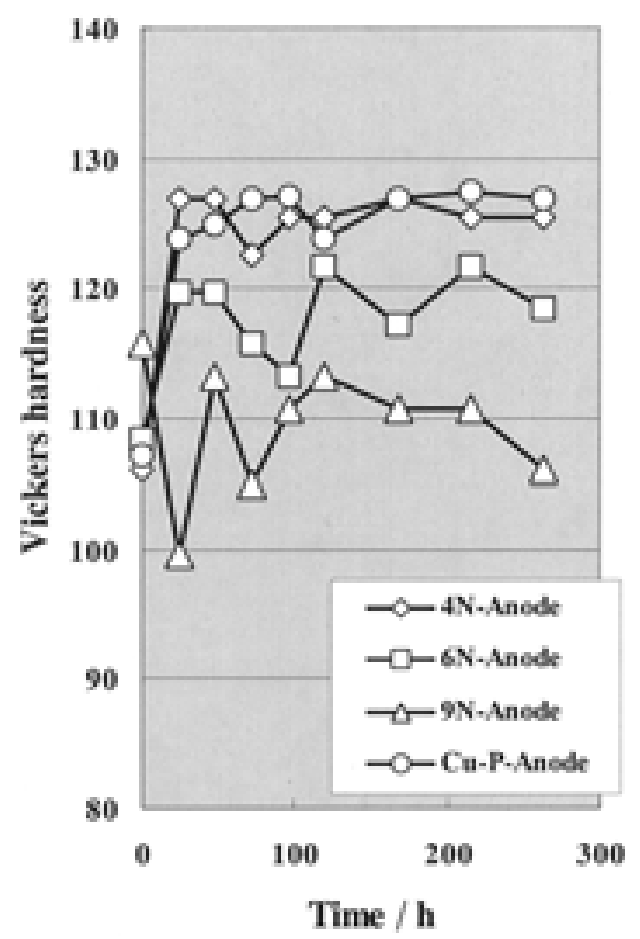

Fig.5. Relation between hardness of copper plating film and annealing time.

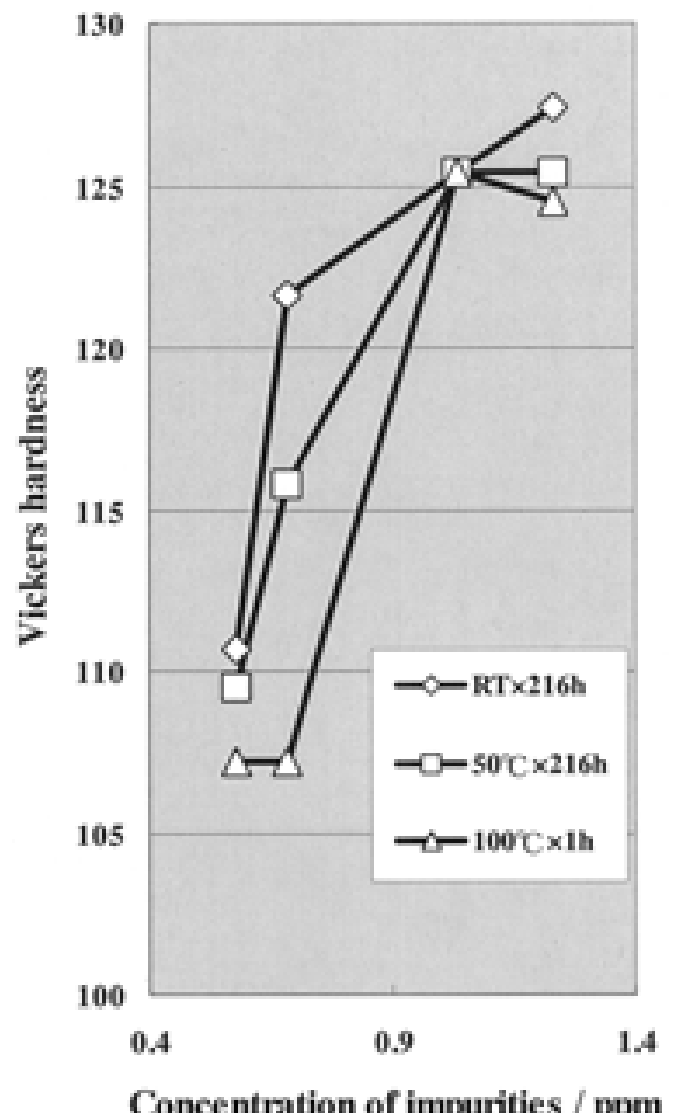

Fig.6. Relation between hardness of copper plating film and impurities. 
超高純度 $\mathrm{Cu}$ のその他の特性を, 次に述べる ${ }^{8)}$.

Fig.7 では, 熱伝導率の温度変化を純度 $4 \mathrm{~N}$ と $6 \mathrm{~N}$ で比 較している. 純度 $4 \mathrm{~N}$ の $\mathrm{Cu}$ は $18 \mathrm{~K}$ がピークとなり, その 時の熱伝導率は $3.1 \times 10^{3} \mathrm{~W} /(\mathrm{m} \cdot \mathrm{K})$ であるが, $6 \mathrm{~N} \mathrm{Cu}$ の熱 伝導率は $8 \mathrm{~K}$ 付近でピークとなり, その值は $3.0 \times 10^{4} \mathrm{~W} /$ $(\mathrm{m} \cdot \mathrm{K})$ となった. Fig.8 は, 等時焼鈍曲線を示しており, $\Phi 2 \mathrm{~mm}$ まで泠間伸線し, 各温度においてアルゴン雾囲気 で3.6 ks 焼鈍したものの引張強さの変化を示している. $6 \mathrm{~N}$ $\mathrm{Cu}$ の半軟化温度は $350 \mathrm{~K}$ 程度であり, $4 \mathrm{~N} \mathrm{Cu}$ の約 $440 \mathrm{~K}$ に 比べて大幅に低下している. Fig.9 は, $6 \mathrm{~N} \mathrm{Cu}$ の極細線の 常温における軟化曲線を示している。 $\Phi 25 \mu \mathrm{m}$ の $6 \mathrm{~N} \mathrm{Cu}$ 室温に放置しておくと, 約 $800 \mathrm{ks}$ で軟化したが, $4 \mathrm{~N} \mathrm{Cu}$ は 変化が認められなかった. Fig.10は, 純度の異なる $\mathrm{Cu}$ に In を添加した場合を示しているが，高純度化した $\mathrm{Cu}$ は微 量の元素を添加するだけで軟化特性に著しい変化を生じて

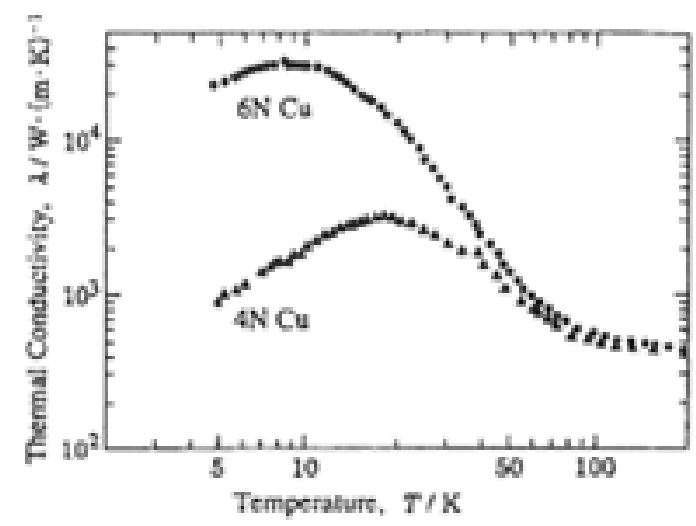

Fig.7. Thermal conductivity at very low temperature.

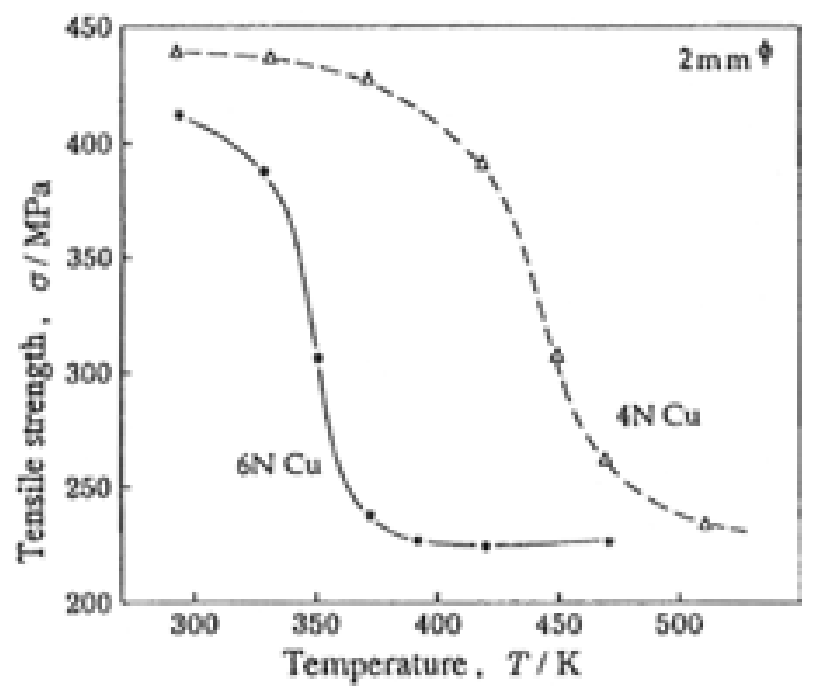

Fig.8. Relation between tensile strength and annealing temperature.

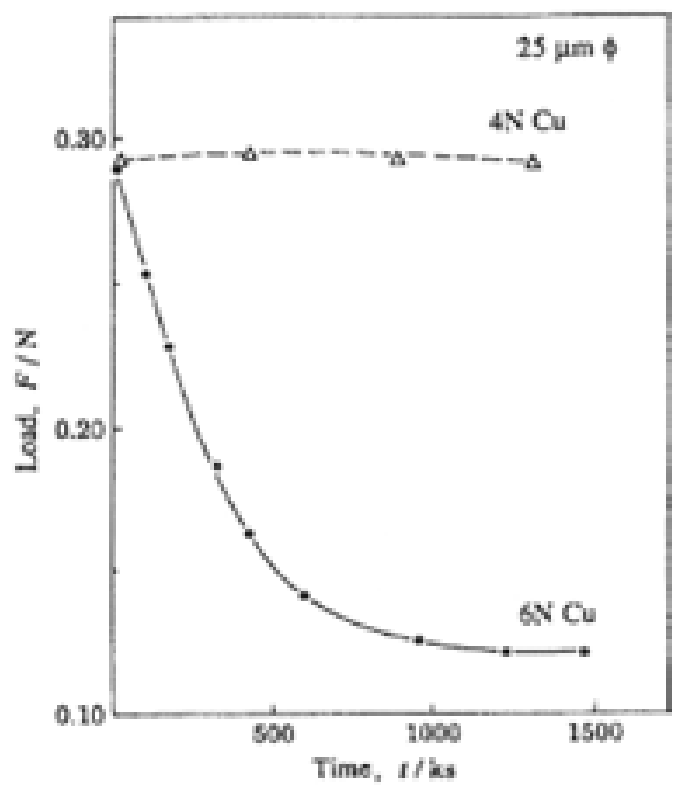

Fig.9. Softening curve of ultra-fine wire at room temperature.

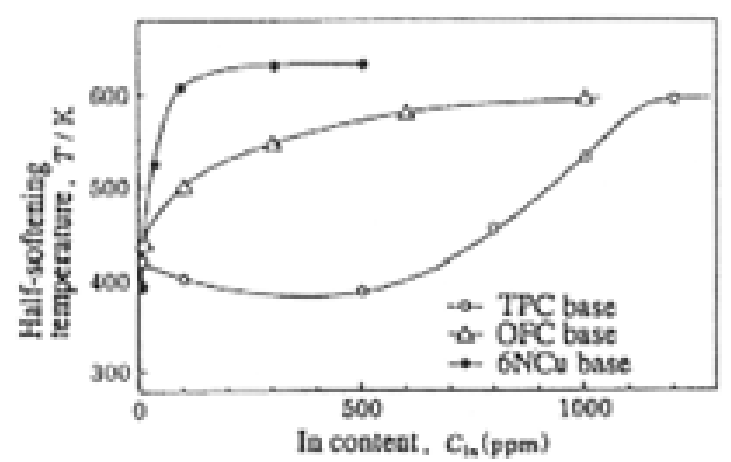

Fig.10. Effect of In content on softening temperature.

いる. 結晶組織は, 不純物量が減少すると粗大化傾向にあ り，その一例を Fig.119) に示す. Cu 中の酸素含有量が少な くなると, 結晶組織が粗大化していることがわかる.

このように, 超高純度 $\mathrm{Cu}$ は市販の $\mathrm{Cu}$ に比べて, 極低温 において電気抵抗が小さく, 低温での熱伝導率が高くな $り$, 再結晶温度も低く, 常温で軟化し, さらに中間温度域 での脆性がほとんどなくなる．

以上のことからわかるように, 超高純度 $\mathrm{Cu}$ の物性をほ んの少し調査しただけで新しい特性が次々と出現してい る.

\section{2 高純度 $\mathrm{Ti}$}

工業用の CP-Ti は, 酸素含有量が多いため延性などにそ しいが, 高純度化すると異なった状況になる. 純度 4N5 Ti と $6 \mathrm{NTi}$ を比較した場合, 引張速度 $10 \mathrm{~mm} / \mathrm{min}$, 線径 $1.0 \mathrm{~mm}$, 標点距離 $70 \mathrm{~mm}$ で行ったものの結果の一例を, Fig.12に 


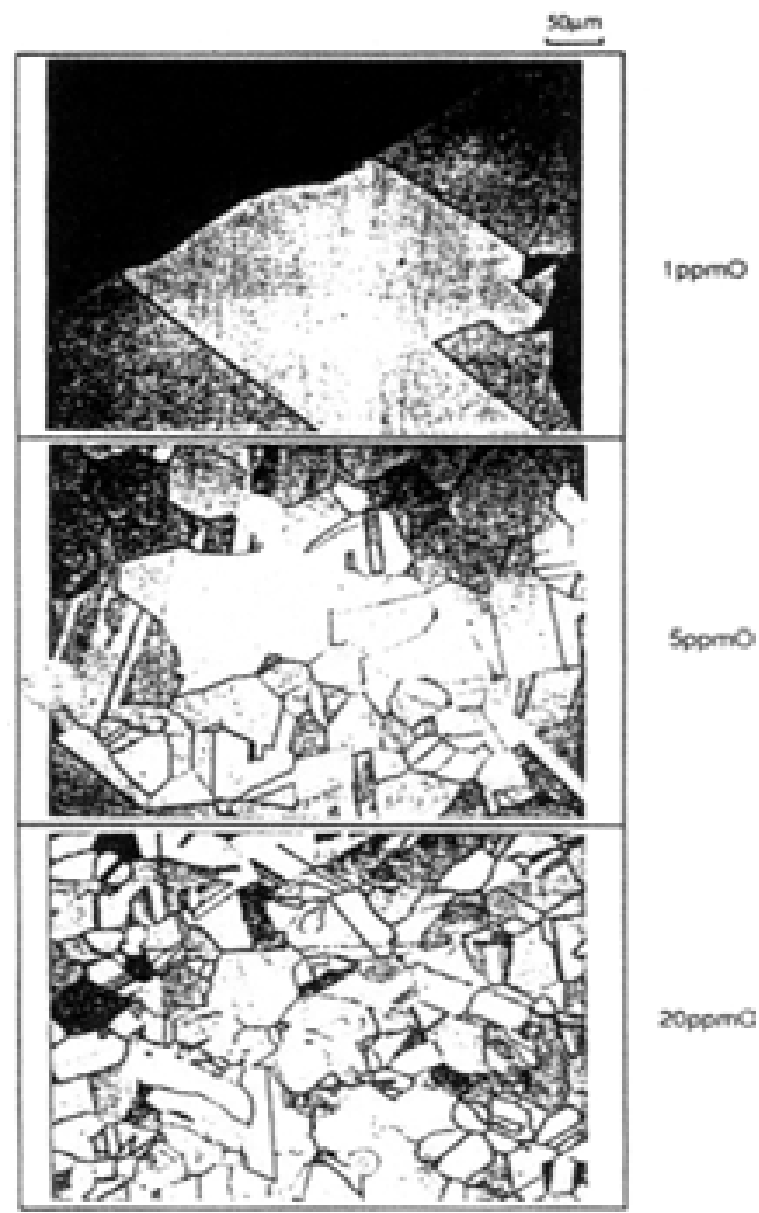

Fig.11. Grain size dependence on purity and oxygen content.

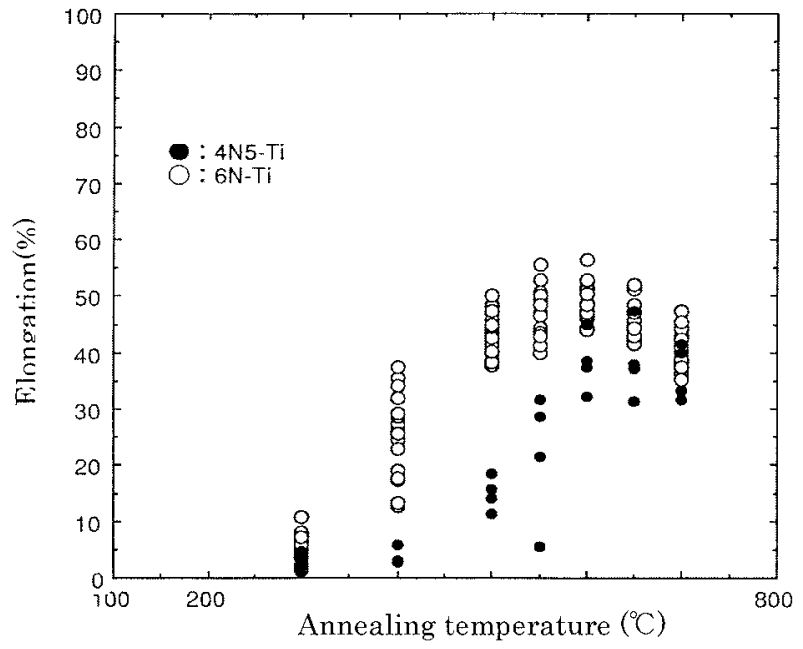

Fig.12. Change of the elongation by the heat treatment temperature after cold workings.

示す. 4N5 Ti は伸びが $923 \mathrm{~K}$ において最大となり $31 \sim 47$ \%であったが, $6 \mathrm{~N}$ Ti は $873 \mathrm{~K}$ において伸びが最大になり $44 \sim 56 \%$ となった. また, 破断応力, 耐力は 4N5 Ti では
$773 \sim 873 \mathrm{~K}$ の間で大きく変化し, それ以上の温度範囲で

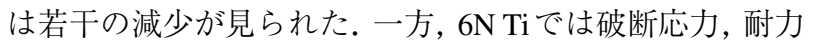
は $573 〜 673 \mathrm{~K}$ の間で大きく変化した。耐食性は, アノー ド動電位分極曲線で調査すると, $6 \mathrm{~N} \mathrm{Ti}$ は自然浸漬電位が 高く皮膜形成後の電流值も低いことから, 工業用 Ti(CP-Ti) よりも耐食性が高いことがわかる. また, $6 \mathrm{~N} \mathrm{Ti}$ は, 自然浸 漬電位からの電流の立ち上がりが鋭く皮膜形成電位(ここ では電流值が平坦になり始める電位）が卑側にある。この ことは, 酸化皮膜形成が早いことを示唆している. CP-Ti と $6 \mathrm{~N} \mathrm{Ti}$ の耐食性の違いは, 表面酸化膜の緻密さによるも のと思われる。

\section{3 合金}

単一の金属だけでなく, 合金でも変化がある. 東北大学の安彦（金属材料研究所）らは, $\mathrm{Cr}-\mathrm{Fe}$ 合金に ついて詳細に研究している ${ }^{10), 11)}$. Cr-Fe 合金において, $\mathrm{Cr}$ 量が増加するにつれて耐食性や強度は増加するが, 加工 硬化や脆化が激しくなるため, 現在実用化されている フェライト系ステンレス鋼のクロム含有量は重量比で $30 \%$ が限界である. Fe-Crの状態図を, Fig.13に示す. 状態図で は $\sigma$ 相が存在しているが, 超高純度金属を用いると $\mathrm{Cr}$ 含 有量 $30 \%$ 以上になっても $\sigma$ 相が現れず，加工可能となり, 大幅に高温特性，耐食特性および加工特性が向上した。

形状記憶合金で用いられているNi-Ti合金でも, Table 7 12) に示すように，破断伸びや最大加工減面率の向上が見ら れる。

\section{4．超高純度金属の将来展望}

超高純度金属材料が，一般金属材料と比較して優れた 特性を示すいくつかの例を述べてきたが，ここでは，高純 度金属および超高純度金属材料が用いられようとしてい る分野をいくつか紹介する.

\section{1 セラミックヒーター13)}

高純度粉末も従来から半導体用途に製造されてきたが, 別の用途にも用いられようとしている.

セラミックヒーターの一つである $\mathrm{MoSi}_{2}$ (二珪化モリブ テン ) ヒーターは, 酸化䨌囲気中の高温使用ヒーター（最 高使用温度 $2123 \mathrm{~K}$ ）としてガラス工業やセラミック焼成 の分野で幅広く使用されている.また, 金属ヒーターの 10 倍以上の出力密度を有することから急速昇温ヒーターと しても注目されている。通常のヒーター（不純物が多いも の）を用いると, Fig.14に示すようにペストと呼ばれる粉 状化現象が生じ断線が生じる。この原因は, 不純物が多い と酸素がヒーターの中に容易に侵入して, Mo と Si の同時 酸化が進み, 表面に粉状の Mo 酸化物が生じるためである. 


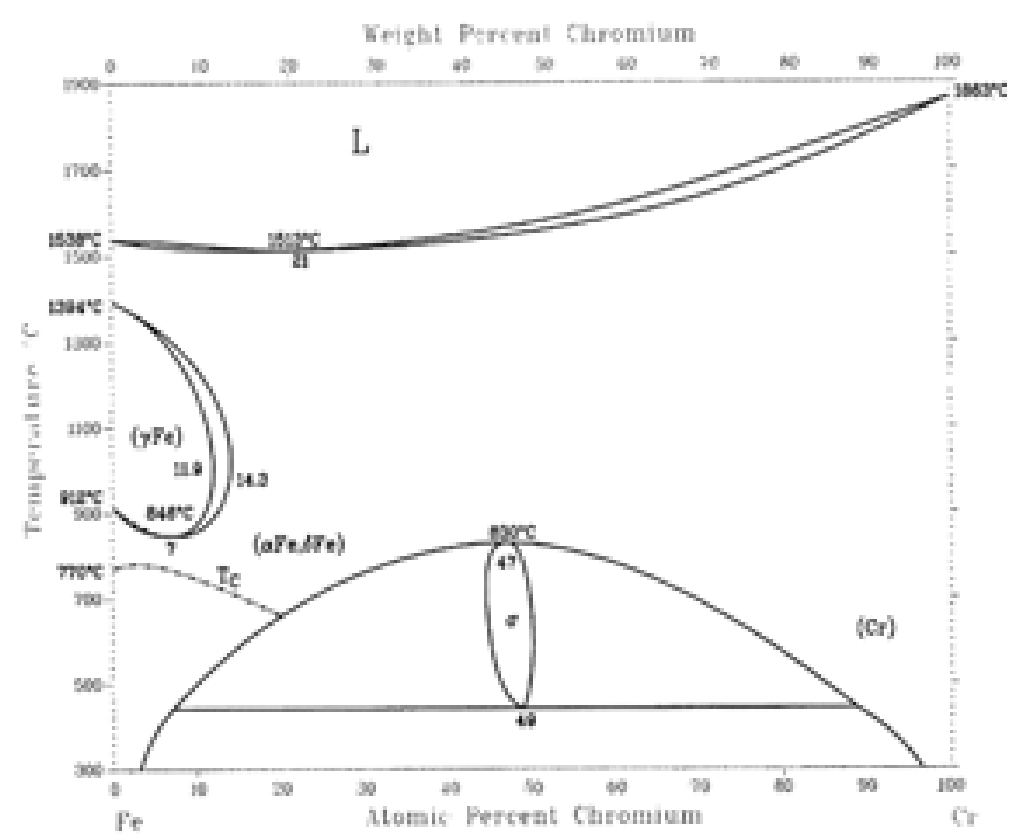

Fig.13. Fe-Cr phase diagram.

Table 7. Impurity content, and mechanical properties in $\mathrm{Ni}$ - $\mathrm{Ti}$ alloy.

\begin{tabular}{c|c|c|c|c|c}
\hline \multirow{2}{*}{} & \multicolumn{3}{|c|}{ Impurity content (ppm) } & \multirow{2}{*}{ Elongation (\%) } & \multirow{2}{*}{ Reduction on area(\%) } \\
\cline { 2 - 6 } & $\mathrm{O}$ & $\mathrm{C}$ & $\mathrm{N}$ & & \\
\hline Conventional & 700 & 350 & 80 & 55 & $45 \sim 50$ \\
\hline High purity & 400 & 20 & 20 & 75 & $65 \sim 70$ \\
\hline
\end{tabular}

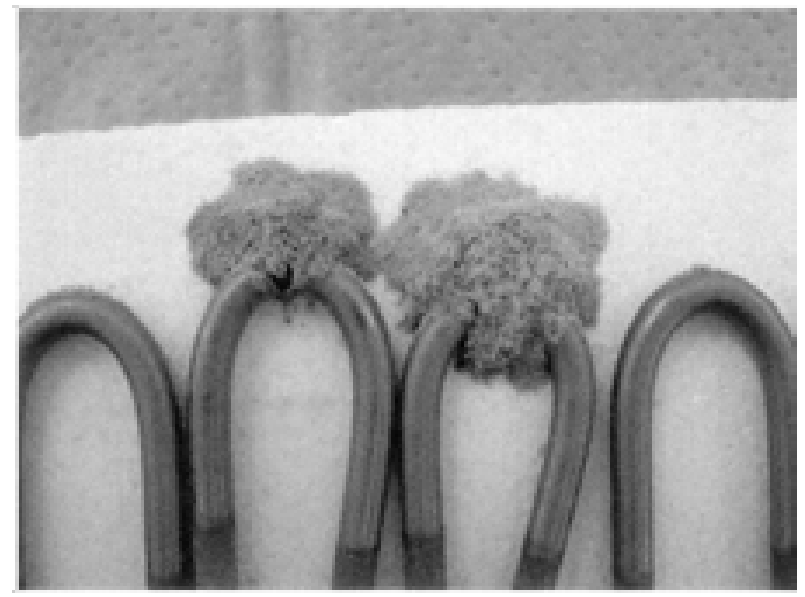

Fig.14. "Pest" on $\mathrm{MoSi}_{2}$ heater elements.

しかし, 高純度品は $773 \mathrm{~K} て ゙$ 長時間保持してもなんら変化 はおきない。これは, 表面に緻密な酸化皮膜が形成されて いるため, 容易に酸素が侵入できないためである。また, Fig.15 に示すように，市販のヒーターを石英管の中に入 れて $1873 \mathrm{~K}$ に通電加熱すると, 高温保持中にヒーター表
面から $\mathrm{Fe}, \mathrm{Na}$ などの不純物が揮発し, 石英管内壁に付着 してしまう。しかし, 高純度ヒーターを用いるとほとんど 不純物が揮発しないことが確認された。このように, 炉内 の雲囲気を污染しないことにより, クリーンな環境が要 求される半導体ウエハの熱処理用途分野での使用が期待 されている.

\section{2 記録材料 14)}

不揮発性メモリーとして有望な MRAM や相変化メモ リーは, 実現すれば, 例えばパソコンで作業中のファイル などがスイッチの入・切で失われず, 切る前の状態から再 起できるなど大きな機能を付与することができる.

相変化メモリーの心臓部に当たる相変化材料には, 例 えば GeSbTe 系やAgInSbTe 系といった書換え可能なCDや DVD の記録材料が検討されている.これは, 非晶質と結 晶質の間の相変態を熱的に誘導して記録し, これに伴う 1 桁以上の電気的抵抗值変化を読み取るものである.

既にナノレベルに突入しているLSIのスケールでの相変 化は, 微量の不純物の偏析が予想され, これが繰返し記録 回数に大きく影響すると考えられる.特に GeSbTe 系は, 


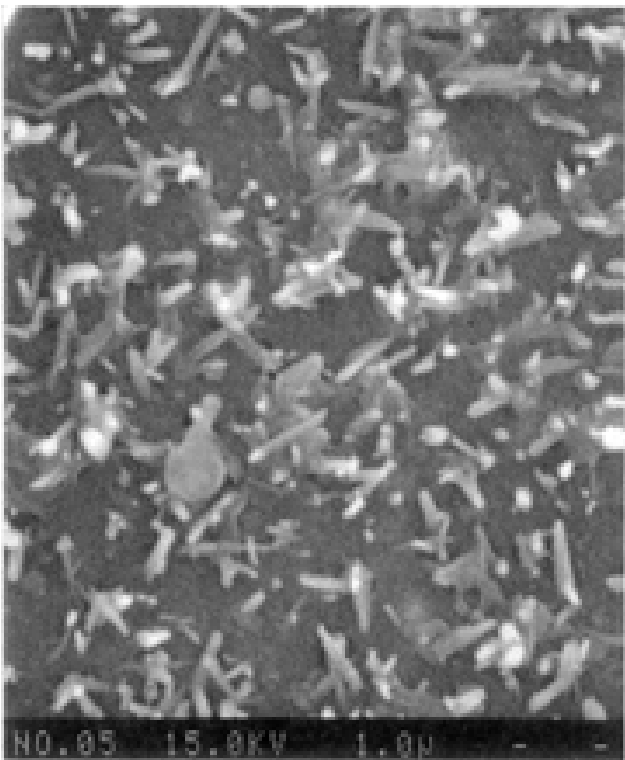

Convential MoSi2

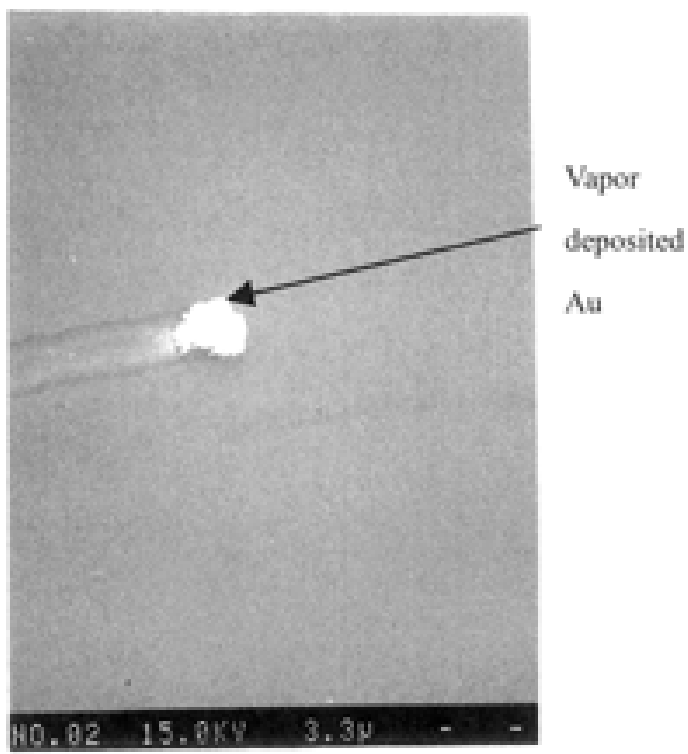

High purity MoSi2

Fig.15. SEM photograph of the impurities adhering to the wall of quartz.

モル比で 2:2:5 の定比化合物であり, 結晶化の際に結晶粒 界などへの不純物の偏析を防ぐための高純度対応が最も 重要である.

スパッタリングプロセスにより形成されるこの記録層 の純度は, ターゲット材料の純度により決定されるので, 高純度ターゲットの製造技術がキーテクノロジーとなる。

\section{3 標準物質試料 ${ }^{15)}$}

超高純度金属は, 温度測定標準試料としても用いられ ている. 融点直上から冷却していくと固相が出始め, 固相 と液相が共存して一定の時間一定の值（温度）を示す.高 純度になればなるほど，一定の值を示す時間が長時間続 く，ところが，純度が悪くなると，なだらかに低下する。 Fe-C 合金の例を, Fig.16に示す.これからわかるように, 高純度品は, 長時間温度の定点として採用できることを 示している.

温度以外にも, 転位論の学問分野や極微量の不純物分 析用などにも標準物質として用いられようとしている。

\section{4 高温金属材料 10), 11)}

クロム基鉄合金は，従来製造できないといわれていた $\mathrm{Cr}$ 含有量 $50 \%$ 以上のものでも, 高純度にすると製造可能 となる。これらの合金は, 現在最高級のニッケルベースの スーパーアロイ, ニッケル基超合金の性能をもしのぐ データが得られている.ニッケル基超合金は超耐熱性の 高強度材料であり, ジェットエンジンやガスタービン発

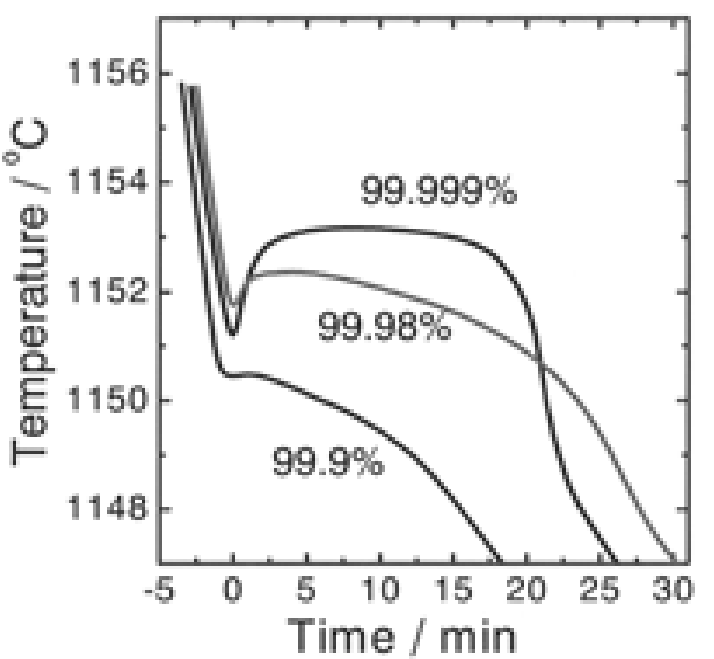

Fig.16. Dependence on material purities for freezing curves of Fe-C.

電機の中枢部材として用いられ, 高温の燃焼ガスでター ビンを回すタービン翼材料であるが, 高純度のクロム基 合金はその代替材料として期待されている。

\section{5 IC 用ボンディングワイヤ 4), 16)}

$\mathrm{Si}$ チップとリードフレームを結ぶボンディングワイ ヤーは, 主に $\mathrm{Au}$ 線が用いられている。この $\mathrm{Au}$ 線は, ボン ディング速度や信頼性が優れているが高価であることか ら，たびたび安価な $\mathrm{Cu}$ 線への変更が検討されてきた。し かし, 問題点が多く一部しか実用化されていなかったが, 
ここへきて 最近の $\mathrm{Au}$ 価格の高騰により再び見直されて くるようになった， Cu線は， $\mathrm{Au}$ 線より変形抵抗が大き いためボール圧着時に Si チップがダメージを受けてしま う。そこで, 超高純度 $\mathrm{Cu}$ を用いると硬さが低下し Si チッ プのダメージを防げるようになる。しかし，ワイヤのルー プの安定性に問題もあるため, ドーパントの特性改良も 行われている。

\section{6 ナノメタル ${ }^{17)}$}

金属材料の微構造をナノスケールで制御することで, 今までに無い機能・性能を発現する材料を「ナノメタル」 と一般に呼んでいる.

「ナノメタル」の製造方法の一つとして, 液相からの急 速冷却がある。急速冷却法による制御では，いったん融点 以下の大過冷却状態にしておいた上で, 結晶相の析出を コントロールする条件がキーテクノロジーとなる。この 際に, 不純物が大きく影響されるため超高純度金属が必 要とされる。そしてこの「大過冷却状態」はナノガラスと 呼ばれ，これを安定化するに，(1) 3 成分以上の多元素系で あること，(2)各成分の原子径の差が $12 \%$ 以上であること， (3)元素間化合物の生成が大きな発熱を伴うこと，が必要 とされる.この過冷却状態から, 当該状態安定性を利用し て希望のナノレベル微構造を制御する。

この急速冷却法による金属ガラスやナノメタルを応用 して, 微細な加工精度を要求される部材・部品や高機能材 料が期待される。例えば, 航空・宇宙分野における Ti 合金 を金属ガラス化することによって強度を2倍にし, 大幅な 機体軽量化が可能となる。ささには, 鍛造の必要も無くな り，製造コストダウンの期待も大きい.

\section{5. 結言}

これまで述べたように, 超高純度金属は, 半導体からナ ノテクノロジーの分野まで領域を広げようとしている. 現在工業用で用いられている金属は, 本来の金属の性質 と大きくかけはなれており,さらに純度を上げ超高純度 化した場合には, 全く異なった新しい物性值が発見され， 根本的に世界が変わることが予想される.ナノテクノロ ジーの開発が進む中, 具体的には, 量子拈よびスピンエレ クトロニクス (ナノエレクトロニクス), マイクロマシン （MEMS）などから高純度金属の要求が高まる可能性が高 い.さらには,ナノメタラジーとしての高純度金属の研究 も盛んになりつつある.このような環境の中, 当社では, 半導体産業で培われた高純度化技術を数多く保有してい ることから，さらなる金属の高純度化を行い,市場に供給 しつつ, あるいは大学などとの提携により金属本来の性
質を見極め, ナノメタラジーの発展の一助になりたいと 思っている.

\section{(文 献)}

1) 高木清一:まてりあ,33(1994), 6.

2）三宅和彦:日本金属学会会報, 31 (1992), 267.

3) 石川幸雄, 三村耕司,一色実:東北大学素材工学研究所 彙報, 51(1995), 10.

4) 吉田秀昭:金属, 1(1988), 14.

5) Akihiko kurosaka, Kazuhiro Tomomatsu and Haruo Tominaga:Fujikura Technical Review, 1992, 51.

6) P.Gregory, A.J.Bangay and T.L.Bird: METALLUGIA May, (1965), 207.

7) 岡部岳雄:SEAJ Journal, 64 (2000), 24.

8）加藤正憲:伸銅技術研究会誌, 35 (1996), 28.

9) 岩村卓郎:新素材, 5(1991), 49.

10）安彦兼次:別冊日経サイエンス 138 , 日経サイエンス 社, 2002,52.

11) 安彦兼次:源流, 3(2001), 46.

12）相場満, 永井博司, 浅川基男:日本金属学会会報, 31 (1992), 541.

13）高村博,宮下博仁:資源と素材, 121 (2005), 176.

14）奥田昌宏:電子材料, 4(2002), 105.

15) Bernd Fellmuth, Kenneth D. Hill : Metrologia, 43(2006), 71

16) 森暁, 小野敏昭, 内山直樹, 中根守久: 高温学会誌, 13 (1987) $2,88$.

17）長坂宏, 東海林昭, 富永亮, 井上明久: 第 1 回金属ガラ ス成形加工技術シンポジウム講演集, 1(2004), 87. 